\title{
Nenets Children's Literature: the History and Specificity
}

\author{
Ekaterina A. Sertakova* \\ Siberian Federal University \\ 79 Svobodny, Krasnoyarsk, 660041, Russia
}

Received 16.02.2016, received in revised form 19.06.2016, accepted 02.08.2016

This article was written as part of the grant named Creating a Corpus of Texts for Children in Their Native Languages (Evenki, Nenets, Dolgan, Nganasan) as a Way of the Unique Preservation of the Indigenous Peoples of Krasnoyarsk Krai, and is devoted to the study of Nenets children's literature. The theoretical part of the article is the rationale for this study. This part determines the object of the study, the purpose and objectives, methodology and directly the source base. The practical part of the work carries out a historiographical review of the study and classification of the Nenets folklore, where the genre of fairy tale takes one of the key places, the specificity of fairy stories, names, acting heroes of fairy tales is revealed, the analysis of such representatives of the children's literature of the northern Nenets people as Boy Susui, Three Shamans, and others, is done. Based on the material of the analysis of the Nenets fairy tale's samples, the article determines the specificity of Nenets children's literature and reveals its educational potential.

Keywords: children's literature, the peoples of the North, Krasnoyarsk Krai, the Nenets, fairy tales, traditional knowledge, cultural values, the worldview.

The work is executed in connection with the project Creating a Corpus of Texts for Children in Their Native Languages (Evenki, Nenets, Dolgan, Nganasan) as a Way of the Preservation of the Unique Cultural Heritage of the Indigenous Small-numbered Peoples of Krasnoyarsk Krai, supported by the Krasnoyarsk Regional Science Foundation.

DOI: 10.17516/1997-1370-2016-9-9-2013-2021.

Research area: theory and history of culture.

\section{Introduction}

The Nenets live in the territory of Krasnoyarsk Krai mainly in the Taimyr Dolgan-Nenets Municipal District, where they have several mono-ethnic villages. The largest number of representatives of this ethnic group is concentrated in the Ust-Yenisei district.

The expeditions and the study of the culture and life of the Nenets people identified a number of problems, which the representatives of this ethnic group face today, namely, the state of the level of health service and education, the quality of life, environment and climate, social disadvantage, etc. Another problem is the gradual extinction of traditional forms of farming and traditional knowledge in the today's globalized world. Representatives of the northern peoples of

(C) Siberian Federal University. All rights reserved

* Corresponding author E-mail address: sertachok@mail.ru 
Krasnoyarsk Krai lose themselves and forget their past, without which the future of these peoples is impossible.

The memory of an ethnos, its history and culture are reflected in the folk art, namely, arts and crafts and folklore.

The study of Nenets literature allows comprehending the folk art of the people deeper, as well as fixing the source of the formation of the culture of the language and ideas about the world. For folklore is directly included in the general system of the ethnos (Putilov, 2003).

The object of the research in this article is Nenets children's literature.

The subject of the research is the cultural identity of Nenets tales-myths.

The purpose of this article is to analyze the samples of Nenets fairy tales-myths and to reveal their ethnographic originality.

In order to achieve this goal, it was necessary to solve a number of problems:

Firstly, to consider the history of collecting, studying and classifying the Nenets folklore;

Secondly, to read the collected materials published in Russian, namely, Nenets talesmyths;

Thirdly, based on the analysis of representative fairy tales-myths, to reveal the uniqueness of Nenets children's books (titles, themes, motifs, the composition of the characters, the educational potential of the fairy tale, etc.).

\section{Research Methodology}

The theoretical views of the researchers, ethnographers and ethnofolklorists B.N. Putilov (2003) and E.T. Pushkareva (2003) were selected as the research methodology.

We used the general theoretical methods of knowledge, such as analysis, synthesis, interpretation, extrapolation, idealization, etc., as well as analytical-descriptive and typological methods, among which the first one allowed fixing frequently used images in Nenets tales, and the second one allowed revealing the specific character of Nenets tales in terms of ethnic characteristics.

The texts of Nenets tales-myths published in Russian in Folklore Anthology of Peoples of Siberia, the North and the Far East (1989) and in the Nenets folklore anthology Tales of Antiquity were chosen as the source of the research (2001).

\section{Literature review}

Today the children's literature of the indigenous peoples of the North is studied all over the world. A special attention is paid to it in the field of the preservation of traditional knowledge and cultural values of ethnic groups.

The articles of M.J. Monette, B. Pothier, N.F Holly and J.T. Rudy appeared to be the most interesting among the most recent publications in international scientific journals.

M.J. Monette in his work Beyond Values and Ideology: Tales from Six North American Indian Peoples (1992) writes that the Native Americans' tales contain the values and beliefs of indigenous peoples, the close relationship with the nature of North Dakota, a reverent attitude to the location and methods of survival in the changing world around. Fairy tales are universal; they do not only reflect the history of the people, but make it possible to design its future as well.

B. Pothier (2015) examines the models of the world that are presented in tales, reveals images, perceived by the representatives of the people consciously and unconsciously, using the example of the Ainu in Japan. The researcher N.F Holly (2015) associates himself with the same view, noting that through the system of characters and situations which they face, tales form an ethnic identity since childhood, thanks to which there is a close connection with the people, place and time. J.T. Rudy in the article American folklore scholarship, Tales of the North American Indians, 
and relational communities (2013) writes that folk tales set social norms of behavior and an ethnic particularity.

B. Sundmark in the scientific article The Idea of North in Canadian Children's Literature Today (2011) notes the important role of visual aids in children's literature. According to him, fairy tales and stories, which are featured by the theme of the North, need to be provided with the pictures of the northern flora and fauna. M.M. Pyterek (2006) offers the training material developed for the indigenous people of North America, in which children's literature is of paramount importance. Using a project-based approach, the author provides a mechanism for working with children, so they do not just read but understand stories, revealing the inherent stereotypes. A lot of research has shown the effectiveness of the work. The researcher identified the transformation of children, their understanding of cultural features and intercultural interactions collecting information through such methods as children's drawings, interviews (both individual and group), large group discussions, small focus groups, and the author's own observation.

Since the subject of research is the tales and myths of the people living in the North of Russia, the key sources were the publications of local researchers.

For example, T.D. Bulgakova (2015) demonstrates the educational potential of the fairy tales of the North in the work with students majored in humanities. She writes that the study of the structure and semantics of the tale develops an analytical thinking and vision of the foundations of culture.

E.A. Kalenchuk and A.R. Banshchikova (2015) consider the problems of the study of the folklore of the indigenous peoples of the North, Siberia and the Far East, paying attention to the scientists who collected and processed the folklore material of indigenous peoples. The classification of the folklore of specific ethnic groups (the Evenki, the Nganasan, the Nenets, the Yessey Yakuts, the Kets, etc.) of the Russian North also take an important place in this article.

The fundamental work for the study of the indicated subject of research was the thesis and the article by the researcher E.T. Pushkareva $(2003,2004)$, who identified the worldview in the traditional representations of the Nenets.

Based on the content of the above publications, it is possible to talk about the need to study the folklore of the indigenous peoples of the North in general and the Nenets in particular, and its popularization.

\section{History of the study of the Nenets folklore}

Notonly scientists, historians, ethnographers, linguists but writers as well dealt with the popularization of the folklore of representatives of the indigenous peoples of the North. There are several periods in the study of the Nenets folklore that can be distinguished, namely, the prerevolutionary, Soviet and post-Soviet periods.

The first written notes of the Nenets ethnic group are found in Russian chronicles of the $11^{\text {th }}$ century. Thus, the indigenous people of the North were fully introduced into the history of the state.

The interest in the Nenets folklore that was oral at that time manifested much later. In 1787 I. Fater published Vada Khasavo in St. Petersburg and only after that the interest in the collection and study of Nenets tales, legends, etc. was sparkled. The attempts to identify the general principles of systematization of plots of fairy tales, stories and legends were made in the second half of the $19^{\text {th }}$ century. However, there were few researchers of theNenets folklore.

More than a hundred years ago, the researchers M.A. Castrén [(Travels in Lapland, Northern Russia and Siberia (1838-1844, 1845- 
1849)] and T. Lehtisalo attempted to identify types of the Nenets folklore, particularly etymological legends, sacrificial prayers-incantations, shamanic songs, myths, prayers-incantations, epic and lyric songs, true stories, riddles, urban legends, myths-fairy tales.

The first domestic Nenets folklore collectors were G. Prokofiev and G. Verbov, the members of the Institute of Peoples of the North, as well as N. Tereshchenko and A. Pyrerka from the Institute of Linguistics of the Academy of Sciences of the USSR. Later, the ethnographer B. Dolgikh and the folklorist Z. Kupriianov collected and classified Nenets oral folk arts. Edited by E.G. Susaia, in 1962, the collected material was got up into the collection Nenets Tales and Mysteries in the original language. As the Nenets writer V. Sangi (1989) notes, during the pre-revolutionary period and more than half of the Soviet period, many scientists came to the study of the Nenets folklore by comparing it with the Russian version, and this was a significant omission. They did not take into account either the historical considerations that affected people, or the dialectical relationship of the people and culture. Many examples of the fiction were attributed to tales that is not quite true.

V. Sangi is a researcher of the Nivkhs, who for many years collected the folklore of the northern peoples inhabiting the shores of the Arctic Ocean, the Kola Peninsula, the Taimyr Peninsula, Siberia and the Far East, Kamchatka and Chukotka to publish the Anthology. His main task was to identify the genuine ethnic folklore (the Nenets, in particular), to separate it from the foreign one, for example, from poorly adapted Russian fairy tales and stories.

E.N. Pushkareva, who was Nenets originally, was able to understand the distinctive spiritual world and the human philosophy of the North in the folklore. She tried to organize the Nenets folklore through the story and popularize it among other peoples of the USSR. Based on the Aarne-Thompson Index, the scientist showed that Nenets tales-myths were not only specific, but could also be viewed in terms of their general cultural significance because of a large number of matches. E.N. Pushkareva highlighted the concept of the universe and the characters populating the universe as the key images of the Nenets folklore.

The poet L. Neniang collected and popularized the Nenets folklore in Taimyr. In her lifetime, she tried to do her best to record as many as possible Nenets tales and legends, proverbs and riddles, and pass them to the following generations. Besides, the author is also known as the translator of the New Testament in the Nenets language. Today her work is continued by a number of Nenets writers and public figures, such as R.P. Iaptune, L. Valei, and others.

Today the written Nenets language is presented to a very limited extent. N.M. Tereshchenko is one of those who was involved in creating the written type of this language, and argued that it was not a literary language in the full sense of the word, and did not have a strong influence on the local dialects. But at the same time it had a meaningful impact on the material and spiritual life of the people. Therefore, it was necessary to consider the territorial types of folklore, such as the Nenets of Ust-Yenisei region in Taimyr.

\section{Specificity of Nenets children's literature}

For more than a century it was possible to collect the material, which is not only available, but which is also open for a further study during the exploration of the features of the language of Nenets fairy tales-myths, the scene composition, a number of key and minor characters, the reflection of social phenomena, culture and history of the ethnos in the written sources.

The Nenets folklore is notable for its genre diversity. It is possible to detect a large number of 
stories and legends, songs, proverbs and riddles in it. But above all, the Nenets folklore is presented by fairy tales, which instill love for culture and traditions in children from an early age.

Tales or vadako, which is more correct in Nenets, demonstrate the idea of ancestors about the world, the forces of nature and its inhabitants, and, of course, the origin of man.

Like in most other cultures, vadakho can be divided into the following types:

- Magic vadakho (about spirits, magic, etc.)

- About man and his life;

- About the living world of nature;

However, it is worth noting that fairy tales are syncretic. The animal images intimate people's thoughts and behavior, magical tales-myths refer to the appearance of the person and the formation of his character and way of life. Everything, in one way or another, is connected with man or Nenets (a real person).

The employees of the Taimyr House of Folk Arts make regular expeditions to replenish the fund of folklore as part of the study, preservation and development of the cultural heritage of the indigenous peoples of Taimyr. Many works of Nenets literature were collected in Nosok, Tukhard and Vorontsovo villages.

Let us analyze the Nenets tales Niakhar Tadebia / Three Shamans, recorded in 1976 by V.D. Iar in Vorontsovo village and Susui Nacheky / Boy Susui, recorded by him in 1973.

It is noteworthy that such words as sacred, earth, shaman, old man, son, daughter, alumnus are often used in the names of Nenets tales. This programs a reverent attitude of children to a said authoritative word at once. The culture of telling a tale-myth contributes to this as well. The older generation, grandparents in chums in particular, often tell children fairy tales. Using musical instruments (playing bow, whistles, tweeters), they create a kind of theatrical performance, taking the child to the archetypal past of all the people.
The selection of stories is connected with the resettlement areas of the Nenets, as well as with ideas, manifested in them. Three Shamans is a fairy tale-myth about the organization of the Nenets world. Boy Susui is a fairy tale about a young man who aspires to become a full-fledged representative of his people of the north.

The fairy tale-myth Three Shamans gives the time and place of action that is typical of Nenets tales-myths, namely, the time of creation of the world and the desert land with a large mountain. There is a large chum on the big mountain, which is a globally used image simulating the structure of the universe. That is the point where different worlds touch. Chum is the starting point and the end point of the characters' movement. Chum is stability at a certain life stage of a person. The fairy tale mentions iron that is the metal of the chum, which rejects evil by Nenets beliefs. The shaman's clothes and boat are also iron. Touching the similar products is considered a cleansing procedure, after which the soul of man is cleaner and easier.

The characters of shamans are not considered human beings, they are born before their appearance, they see the true structure of the world (the upper-middle-lower worlds), and cross its borders easily. There are three characters (the older, the medium, and the younger brothers). It is worth noting that in the Nenets culture the number three has a sacred value of the order that is Cosmos. Another important number is seven. Exactly seven days are necessary for shamans to get to the heavenly father's home and reach the cave of the evil spirit.

The upper world is run by the heavenly father, who is loudly loud.

The lower world is run by grandpa evil spirit.

Thus, the relationship between the shamans and the world of the Cosmos is revealed, as well as the mission of the shamans that is to serve 
the people and bind them with the heaven and the underworld, maintaining the harmony of the Universal Being, becomes clearer.

The fairy tale-myth Boy Susui forms the image of people and family (father, mother, brother and sister), where everyone does his own thing. His father fished, the boy caught partridges, the women practiced agriculture. The familiar world was disrupted due to a collision with a strangersavage, who caused the missing fish in the river. The son was forced to leave his native chum to overcome the obstacle. He takes the traditional garments of clothes and management with him, such as bakari, mali, arrows and a bow, which supports his relation to their native land. It took him seven days to go up the river that is a very important point of action. It is the journey of the character by which we get to know the structure of the world. Fairy tales often say that you cannot walk up the river, as this is the place of fathers' death. You can go down by the river, since the lower world is more mastered and not dangerous.

Going up the river, the boy shows courage and fearlessness in the face of the unknown. Moreover, he is ready to fight with the giant, for the welfare of his land and family.

The description of the character's journey has something in common with the movements of the shamans in different spaces of the universe. Their ways go through the lands of enemies or patrons in the same way, which are independent spaces.
While traveling, the boy experiences the rite of initiation, becomes an adult. At first, all seems great and irresistible to him, namely, a large lake, a large chum, a thick forest. Then, these characteristics do not occur. Defeating the enemy, the boy turns into a full-fledged member of the family. As soon as he returns to his chum, his parents no longer live in poverty. All returned to its seats, the cosmic order restored.

The very moment of the enemy's murder is interesting. The boy defeats him not by force, but by his cunning, 'Lie down on a tree, I will measure your height, and you will make a coffin for your daughter'. Traditional trickery helps to behead the giant. Such antics occurring in other fairy tales-myths (Sly Ostiak, How the death was killed, Junior Khanty, etc.) express the people's idea of the ethnic group that is love for life, the desire to fight against the evil, which is sent by the will of God for the sake of harmony in the world.

Based on the viewed stories of fairy tales-myths, we can say that there is the real beginning (ontology of the people) in traditions. Folklore is not fiction; it is a story of a people, their perception of the world, a code of their life. The scenes and composition of the characters of the fairy tales-myths mentioned above reflect different facets of the material and spiritual culture of the people, forming the ethnic identity of a small representative of the Nenets ethnos.

\section{References}

Anthology of folklore peoples of Siberia, the North and the Far East. (1989). Krasnoyarsk. Krasnoiarskoe knizhnoe izdatel'stvo.

Berezkin, Y.E. (2015). Siberian Folklore and the Na-Dené Origins, In Archaeology, Ethnology and Anthropology of Eurasia.

Bulgakova, T.D. (2015). Studencheskie sochineniia, osnovannye na strukturnosemanticheskom analize skazok narodov Severa, kak vspomogatel'noe sredstvo pri osvoenii metodov analiticheskogo opisaniia skazok [Student compositions based on structural and semantic analysis of the tales of the North, as an aid in the development of methods for the 
analytical description of tales], In Pis'ma v Emissiia. Offlain [Letters to Emissions. Offline], (3), 2341.

Far North Tales: Stories from the Peoples of the Arctic Circle. (2011), In Library Journal, 136 (12), 106.

Forbes, B.C. (2013). Cultural Resilience of Social-ecological Systems in the Nenets and YamalNenets Autonomous Okrugs, Russia: A Focus on Reindeer Nomads of the Tundra, In Ecology \& Society, 18 (4), 1-16. DOI: 10.5751 / ES-05791-180436.

Holle, N.F. (2015). "Living Memorials to the Past": The Preservation of Nikwasi and the "Disappearance" of North Carolina's Cherokees, In North Carolina Historical Review, 92 (3), 312337.

Iamidhy lakhanaku (2001). Skazki sedoi stariny [Tales of antiquity], In Nenetskaia fol'klornaia khrestomatiia [Nenets Folk Anthology]. Moscow, Izdatel'stvo Russkaia Literatura.

Il'beikina, M.I. (2014). Osobennosti vizual'no-antropologicheskikh issledovanii indigennykh narodov [The features of visual-anthropological studies of indigenous peoples], In Sovremennye problemy nauki i obrazovaniia [Current Issues of Science and Education], 4, 594.

Kalenchuk, E.A., Banshikova, A.R. (2015). Istoriia izucheniia literaturnogo fol'klora u korennyh i malochislennyh narodov Severa, Sibiri i Dal'nego Vostoka [The history of the literature folklore research of the indigenous peoples and small-numbered peoples of the Russian North, Siberia and Far East], In Problemy Sotsial'no-ekonomicheskogo razvitiia Sibiri [The Problems of Social and Economic Development of Siberia], 3, 62-66.

King, A.D. (2013). Far North Tales: Stories from the Peoples of the Arctic Circle, In Marvels \& Tales, 27 (1), 125.

Kistova, A.V. (2013). Stanovlenie filosofii kyl'tury kak metodologicheskoi osnovy gumanitarnogo znaniia [The formation of the philosophy of culture as a methodological basis of human knowledge], In Sovremennye problemy nauki i obrazovaniia [Current Issues of Science and Education], 1, 401.

Kolesnik, MA (2014). Obzor izucheniia fol'klora korennykh narodov Severa [The Review of the Folklore Research of the Indigenous Peoples of the North]. Litera, 3, 39-59.

Koptseva, N.P. (2014). K voprosu o gosudarstvennoi politike v oblasti sokhraneniia iazykov korennykh malochislennnykh narodov Severa [On the issue of public policy in the field of preserving the languages of the indigenous peoples of the North], In Arktika i Sever [The Arctic and the North], $16,34-40$.

Koptseva, N.P., Seredkina, N.N. (2013). Konstruirovanie pozitivnoi etnicheskoi identichnosti [The construction of a positive ethnic identity in a multicultural system]. Krasnoyarsk, Siberian Federal University.

Koptseva, N.P., Nevolko, N.N., Reznikov, K.V (2013). Formirovanie etnokul'turnoi identichnosti v sovremennoi Rossii s pomoshch"iu proizvedenii natsional'nogo iskusstva (na primere evenkiiskogo eposa i dekorativno-prikladnogo iskusstva) [The formation of an ethnocultural identity in modern Russia with the help of the works of national art (based on the example of the Evenk epic and arts and crafts)], In Pedagogika Iskusstva [Pedagogy of Art], 1, 1-15.

Koptseva, N.P., Sertakova, E.A., Il’beikina, M.I., Zamaraeva, Iu.S., Libakova, N.M., Bakhova, N.A., Luzan, V.S., Reznikova, K.V., Kistova, A.V., Pimenova, N.N., Nevolko, N.N. (2011). Kul'tura korennykh i malochislennykh narodov Severa v usloviiakh global'nykh transformatsii [The culture 
of indigenous peoples of the North in the conditions of global transformations]. St. Petersburg, 174.

Koptseva, N.P., Bralkova, A.V. Gerasimova, A.A., Govorukhina, Iu.A. et al. (2015). Novaia art-kritika na beregakh Eniseia [New art critic by the Yenisei side]. Krasnoyarsk, Siberian Federal University.

Libakova, N.M., Sertakova, E.A. (2014). Kul'turologicheskoe issledovanie korennykh malochislennykh narodov Severa Krasnoiarskogo kraia: rezul'taty ekspertnogo interv'iu [Cultural studies of indigenous peoples of the North of Krasnoyarsk Krai: results of the expert interviews], In Sovremennye problemy nauki i obrazovaniia [Current Issues of Science and Education], 4, 598.

Monette, M.J. (1992). Beyond Values and Ideology: Tales from Six North American Indian Peoples, In The American Indian Quarterly, 16 (4), 600.

Nikolaeva, I. (2015). On the expression of TAM on nouns: Evidence from Tundra Nenets, In Lingua, 166 (A), 99-126. DOI: 10.1016 / j.lingua.2015.08.006.

Pimenova, N.N. (2015). Korennye malochislennye narody v sovremennoi situatsii: ob"em i soderzhanie poniatiia [Indigenous small-numbered peoples in the current situation: the scope and content of the concept], In Sotsiodinamika [Sociodynamics], 1, 112-134. DOI: 10.7256 / 24097144.2015.1.14249. URL: http://e-notabene.ru/pr/article_14249.html

Pothier, B. (2015) 'A walking Man from the far North' - art, craft and the emergence of consciousness: A speculative tale, In Technoetic Arts: A Journal of Speculative Research, 13 (3), 351358.

Pushkareva, E.T. (2003). Kartina mira v fol'klore i traditsionnykh predstavleniiakh nentsev. Dissertatsiia na soiskanie stepeni doktora istoricheskikh nauk [The worldview in folklore and traditional representations of the Nenets. Doctor Thesis in Historical sciences]. Moscow.

Pushkareva, E.T. (2004). Images of the Word in Nenets Folklore, In Anthropology \& Archeology of Eurasia, 42 (4), 64-84.

Putilov, B.N. (2003). Fol'klor i narodnaia kul'tura [Folklor and popular culture]. Moscow.

Pyterek, M.M. (2006). How Can a Teacher Begin to Help Her Kindergarten Students Gain "Authentic" Cultural Understandings about Native North Americans through Children's Literature?, In Online Submission, 262.

Razumovskaya, V.A. (2012). Izometriia v lingvistike i perevodovedenii: rasshirenie kategorial'noi paradigmy [Isomerism in linguistics and translation studies: an extension of the categorical paradigm], In Iazyk i kul'tura [Language and Culture], 4 (20), 49-61.

Razumovskaya, V.A. (2015). Kognitivnye osobennosti avtorskogo perevoda poezii [Cognitive features of the author's translation of poetry], In Kognitivnye issledovaniia iazyka [Cognitive Language Studies], 22, 521-523.

Reznikova, K.V. (2014).K voprosu ob utochnenii poniatii "etnos" i "etnich'nost" [On the issue of clarifying the concepts of ethnos and ethnicity], In Sotsiodinamika [Sociodynamics], 12, 90-102. DOI: 10.7256 / 2409-7144.2014.12.13913. URL: http://e-notabene.ru/pr/article_13913.html

Reznikova, K.V. (2016) K voprosu ob epicheskom kul'turnom nasledii korennykh malochislennykh narodov Krasnoiarskogo kraia [On the issue of the epic cultural heritage of the indigenous smallnumbered peoples of Krasnoyarsk Krai]. Litera, 2, 20-34. DOI: 10.7256 / 2409-8698.2016.2.18917. URL: http://e-notabene.ru/fil/article_18917.html 
Rudy, J.T. (2013). American folklore scholarship, Tales of the North American Indians, and relational communities, In Journal of American Folklore, 126 (499), 3.

Sundmark, B. (2011). The idea of North in Canadian children's literature today, In Jeunesse: Young People, Texts, Cultures. Summer, 3 (1), 152. University of Winnipeg, Centre for Research in Young People's Texts and Cultures.

Volzhanina, E.A. (2009). Demography of the Siberian Nenets in the First Third of the $20^{\text {th }}$ Century, In Archaeology, Ethnology and Anthropology of Eurasia, 37 (1), 118-128. DOI: 10.1016 / j.aeae.2009.05.014.

Zamaraeva, Iu.S. (2015). Global'nye transformatsii, kotorye perezhivaiut indigennye narody Severa [Global transformations that the indigenous peoples of the North are experiencing], In Sovremennye problemy nauki i obrazovaniia [Current Issues of Science and Education], 1-1, 1882.

\title{
Ненецкая детская литература: история и специфика
}

\author{
Сибирский федеральный университет \\ Россия, 660041, Красноярск, пр. Свободный, 79
}

Е.А. Сертакова

Статья написана в рамках гранта «Создание корпуса текстов для детей на родных языках (эвенкийский, ненеикий, долганский, нганасанский) как способ уникального сохранения КМНС Красноярского края» и посвящена изучению ненеикой литературы для детей. Теоретическая часть статьи представляет собой обоснование необходимости проведения данного исследования. В данной части определены предмет исследования, цель и задачи, методология и непосредственно источниковая база. В практической части работы проводится историографический обзор изучения и классификачии ненечкого фольклора, где одно из ключевых мест занимает жанр «сказка», выявляется специфика сказочных сюжетов, названий, действующих героев сказок, проводится анализ таких репрезентантов детской литературы северного народа ненџы, как «Мальчик Сусуй», «Три шамана» и т.д. На материале анализа образиов ненеикой сказки выявляется специфика ненеикой детской литературы, вскрывается ее образовательный потенциал.

Ключевые слова: детская литература, народы Севера, Красноярскийо край, ненцы, сказки, традиционные знания, культурные ценности, картина мира.

Работа выполнена в связи с проектом «Создание корпуса текстов для детей на родных языках (эвенкийский, ненецкий, нганасанский, долганский) как способ сохранения уникального культурного наследия коренных малочисленных народов Красноярского края», поддержанным Красноярским краевым фондом науки.

Научная специальность: 24.00.01 - теория и история культуры. 